\title{
The Roosevelt Image on Trial: \\ FDR, the Radio, and the Supreme Court Battle of 1937
}

\section{Tony McCulloch}

\section{Introduction}

On 10 April 1937, the Gridiron Club, the exclusive association of Washington DC press bureau chiefs, held its annual spring dinner at the Willard Hotel. There could be only one issue to provide the central theme for the evening's topical entertainment - the controversy surrounding President Franklin D. Roosevelt's proposal to reorganize the Supreme Court by adding a new justice for every sitting judge over the age of 70. The so-called 'court-packing' plan would have increased the membership of this august body from its current complement of nine to fifteen. Attending the prestigious Gridiron dinner as guests were FDR, his son James, Vice President John Nance Garner, other Cabinet officials, members of Congress, and prominent leaders of business and labour. Three Supreme Court judges were also present Associate Justices James Clark McReynolds and Harlan Stone and Chief Justice Charles Evans Hughes, who was 75 the next day and received a rendition of 'Happy Birthday to You' from Gridiron members.

FDR attended the Gridiron dinners throughout his presidency without ever really enjoying them. On this occasion he made an uncontroversial speech that contained only one indirect reference to the age of retirement and a mild joke at the expense of his vice president - a critic of the Court proposal. ${ }^{1}$ In contrast, the issue dominated the various satirical sketches performed by Gridiron members that evening. One skit, located in 'old Castile,' portrayed FDR as 'Don Quixote' interacting with his henchman, 'Sancho Panza Garner'. 'Seest thou not yon castle of finance?' Don Quixote remarks to his sidekick. 'There lies 
some poor forgotten wight under dire oppression to whose relief I am brought hither.'

'Them's windmills, Boss,' answers Panza. 'They grind the corn. They're useful.'

In another skit, located in what was described as the 'modest suburban home of a prince of privilege,' a group of 'economic royalists' gathered by a fireside to hear FDR on the radio. A female listener was immediately won over. 'From now on I'm a New Dealer,' she declared. 'You couldn't understand a word he said,' protested one of the others. 'Of course not,' she replied. 'But what difference does it make? Oh, that lovely voice!' This exchange was accompanied by a song that extolled the virtues of the president's radio performances.

We hear a voice which softly rings

The Voice on the Radio.

It promises so many things

The Voice on the Radio.

In dreams we drift thru a twilight haze

Under the spell of a magic phrase

And visions fair of Happy Days

The Voice on the Radio.

The final act of the evening saw the fifteen members of the new Supreme Court walk on to the stage to the 'March of the Toys,' played by the Marine Band Orchestra. 'This court is far too crowded,' said one justice. 'What do you expect in a packed court - a private room and bath?' replied another. When the Chief Justice asked for nominees to join the Supreme Court, anyone contributing more than $\$ 1,000$ to the 1936 Democratic campaign could put his own name forward, while smaller donors had to settle for the Circuit Courts of Appeal. A messenger from the president then arrived with the instruction to hurry up declaring the new 
laws constitutional as it had already taken two hours to get them through Congress. When the Chief Justice pointed out that he did not know what was in them, he was told not to worry as nor did Congress. To which he replied, implicitly drawing a contrast between the obedience FDR expected of today's judiciary and the judicial giants who had established the independence of the third branch of national government in the early republic: 'Gentlemen of the court, get out your rubber stamps! And, above all, keep your minds off John Marshall!’2 The fact that the 1937 Gridiron dinner was so dominated by the Supreme Court battle underlined its significance at the start of FDR's second term and the integral role of the media in the controversy. The image its satirical sketches conveyed of Roosevelt was that of a patrician reformer concerned to stand up for the needs of the 'forgotten man' and his family against the opposition of the 'economic royalists,' namely the anti-New Deal business elite. They additionally portrayed him as a leader with almost mystical powers of persuasion, especially via the medium of radio. This was the common image of FDR in the wake of his landslide re-election as president in November 1936. It also accords with the scholarly perception of him as a consummate politician and leader. Historian William Leuchtenburg referred to Roosevelt as 'the Great Campaigner,' while political scientist Richard Neustadt considered him the greatest exponent of the 'power to persuade,' the essential instrument in a president's political armoury. ${ }^{3}$

As the Gridiron skits demonstrated, the Supreme Court controversy raised concerns about FDR's methods and motives in advocating such a far-reaching change in the judicial branch of government without seeking a constitutional amendment. It also called into question his ability to persuade the American public, notably through his mastery of radio broadcasting, that he was pursuing the right course for the nation rather than just for himself. Thus, in a very real sense, the Roosevelt image as a great reformer and a 'Great Campaigner' was on trial during the Supreme Court battle of 1937. In exploring this aspect of the 
controversy, this essay begins by considering the nature and origins of FDR's image as a New Dealer and political communicator in his first term. It then examines the Supreme Court battle and the media's role in it, before assessing whether the outcome dented perceptions of FDR as the embodiment of the great reformer and great communicator. Finally, by way of conclusion, the essay discusses the resilience of the 'Roosevelt image' that continues to undergird his twenty-first century reputation as a great president. ${ }^{4}$

\section{The Roosevelt Image}

Presidential image, is of course, a multi-faceted concept and, like beauty, it lies largely in the eye of the beholder. It is a construct of, among other things, public opinion, the political elite, the academic community and the cultural media. There is also a distinction to be made between presidential image as perceived by domestic and foreign audiences. In addition, it is important to note that although FDR's electoral success was second to none, he was both a unifier and a divider during the Great Depression years. He was a hero to the common people who made up the bulk of his voter support; he was a traitor to his class insofar as many in the upper stratum of society were concerned; and he was the propagator of alien doctrines to his conservative political opponents, both Republican and Democrat, as the architect of big-government liberalism that supplanted the traditional ascendancy of individualism and states' rights in American political culture.

Until the New Deal transformed it, the Democratic party had supported Jeffersonian ideals of small government and predominantly represented the interests of the white South in national politics. By 1936, FDR's socio-economic programmes had mobilized the support of a new urban voter coalition outside Dixie that would give his party a lock on the presidency until the end of the 1960s. Its constituent elements included Northern city dwellers, ethnics, labour union members, African Americans, women and the unemployed, all of whom benefited from his expansion of federal authority and responsibility. By contrast, more 
conservative Democrats, mainly but not exclusively based in the South, regarded the New Deal as a threat to constitutional principles of limited national government and the sovereignty of the states. ${ }^{5}$

Historians generally have a positive image of FDR and rank him alongside George Washington and Abraham Lincoln as one of America's three greatest presidents. For James McGregor Burns, his first major biographer and arguably the best, 'Roosevelt was one of the master politicians of his time, certainly the most successful vote getter. His political artistry grew out of long experience with the stuff of American politics: men's ambitions, fears, and loyalties operating through conventions, primaries, elections, offices, constitutions, opinion agencies.' Referencing Machiavelli's view that a leader needs to show boldness and cunning at different times, he entitled the first volume of his FDR biography, The Lion and the Fox. More recently, Robert Dallek has written: 'Roosevelt, like his cousin Theodore, was an instinctively brilliant politician,' who 'principally relied on his feel for the public mood to guide him in leading the country'. Nor is this view of FDR confined to US historians - a poll of British academics in 2011 rated him America's greatest president, ahead of both Washington and Lincoln. ${ }^{6}$

When examining the nature of FDR's political image, and especially the role of the media in its construction, it is important to note that it originated at a time when radio and newsreels were in their infancy. Key elements of FDR's image, regarding his personal qualities, his words and his actions, had already been formed before he became president, but it was only after he entered the White House that they reached full maturity with the help of new media. A significant early influence was the family name that benefitted from association with the dynamism and progressivism of Theodore Roosevelt, FDR's distant cousin. Woodrow Wilson was not oblivious to the advantages of including a Democratic Roosevelt in his administration when appointing the young FDR Assistant Secretary of the 
Navy - a post occupied by his illustrious relative in the Spanish-American War of 1898. Franklin Roosevelt served in this capacity during the Great War and, like 'Uncle Teddy,' he emerged from his wartime experience with his reputation enhanced, if not quite to the same extent. $^{7}$

Like his eminent forbear, FDR climbed another rung on the political ladder with his nomination as vice president in 1920, an elevation reflecting Democratic hopes that his illustrious name would attract support from progressive Republican voters. The main medium for the formation of political image at this time remained the press but newsreels were gaining in importance - and FDR became a star in both during the 1920 campaign. Following his vice-presidential nomination, the New York Times gave Roosevelt a big spread on its front page and newsreel footage showed him as a tall, handsome figure, with a winning smile and an adoring family - Eleanor and their five children, plus doting mother Sara. Notwithstanding the landslide Republican victory, the 38-year old FDR's energetic campaigning provided a beacon of hope for Democratic revival and marked him out as a future presidential contender $^{8}$

Roosevelt's protracted convalescence after contracting polio in 1921 was a great personal setback but did not kill his political ambition. With the assistance of Eleanor Roosevelt and Louis Howe, his faithful adviser, he was able to enhance his public image at a time when the Democratic party was badly divided over Prohibition, the Ku Klux Klan and immigration. His 'Happy Warrior' speech on behalf of Al Smith's bid for the Democratic presidential nomination at the 1924 national convention in New York City won widespread praise from pundits and politicos both for the quality of its delivery and the bravery he showed in making his way to the podium on crutches for his return to the political spotlight. Though failing to gain the nomination in 1924, Smith won it four years later with the help of another nominating address by FDR at the national convention in Houston. On this occasion, 
Roosevelt got to the podium not on crutches but supported by the strong right arm of his son James, who performed a similar role on many subsequent occasions when FDR was Governor of New York and later President. ${ }^{9}$

Smith in turn persuaded a reluctant Roosevelt to run for governor of New York to boost his own chances of winning the Empire State in his presidential race against Herbert Hoover. Sensing that the Republican tide was too strong, FDR preferred to bide his time to run for president in 1936, but he was fearful of becoming a pariah in his own party if he ignored its presidential candidate's call to arms. Smith predictably went down to defeat, even losing his home state of New York, but Roosevelt won the gubernatorial race with a vigorous campaign that bucked the nationwide GOP trend. Like Theodore Roosevelt before him, FDR used the New York governorship to establish a national reputation, proving himself a creative and dynamic state leader in facing the growing challenge of the Great Depression in the early 1930s. This record was instrumental in propelling him to the Democratic nomination for president in July 1932. Signifying his determination not to be bound by orthodoxy if he won office, he broke precedent by flying to Chicago, where the Democratic national convention was in session, to accept the nomination in person. Addressing the delegates, he said: 'Let it be symbolic that in so doing I broke traditions. Let it be from now on the task of our Party to break foolish traditions.' Pledging 'a new deal for the American people,' he mounted an energetic campaign that promised strong action against the economic crisis if elected president without being specific about what he intended to do. The unpopular incumbent Herbert Hoover proved no match for the dynamic challenger - lacking a record to defend, his efforts to portray his opponent as an untried second-rater got nowhere, as did his later attempts to depict him as a dangerous radical. ${ }^{10}$

The unobtrusive physical support from sons James and Elliot and others (notably military aide Edwin 'Pa' Watson), during Roosevelt's public appearances as presidential 
candidate and then president was an important aspect of what one historian has called 'FDR's splendid deception.' With the collusion of the media (reinforced by Press Secretary Stephen Early's strict rules about how FDR was to be photographed and filmed), he succeeded in hiding the true extent of his disability from the American public and, indeed, the world. In the 1932 campaign, too, Roosevelt and his aides misleadingly framed his condition as temporary and likely to continue improving, a narrative that paralleled the promise of economic recovery he offered the nation. In fact, FDR remained wheelchair-bound for the rest of his life and needed assistance to undertake almost any activity that would have involved use of his legs. Had the full scale of his paralysis been known to the public, he would likely never have made it to the White House. Even if he had won election as president, it is almost inconceivable that he could have developed and sustained the image of being a strong leader if he was widely perceived as incapable of unassisted mobility in the wake of his polio attack. $^{11}$

\section{The 'Great Campaigner'}

From the moment he took office with the nation's financial system on the verge of meltdown Roosevelt exuded an image of confidence in his ability to put things right. His Inaugural Address on 4 March 1933, in which he famously declared that Americans had 'nothing to fear but fear itself,' set the tone for bold and optimistic leadership that contrasted markedly with Hoover's hesitation and pessimism in the face of the crisis. On 6 March he declared a 'bank holiday' that temporarily closed financial institutions to prevent further runs; on 9 March he secured and signed legislation from Congress giving his administration authority to take steps to restore confidence in the banks; and on 12 March he have his first Fireside Chat explaining his intentions and asking people to keep their money in the reopened banks, a request that elicited an overwhelmingly positive response. ${ }^{12}$ 
Roosevelt's Republican predecessors, Calvin Coolidge and Hoover, had used radio as a medium of communication, but neither came close to matching him as a speaker over the airwaves. The first Fireside Chat was broadcast on a Sunday evening, a day and time when he would be heard by the largest audience of the week. FDR's calm and measured explanation of the banking crisis and the steps he would take to resolve it did much to restore popular confidence in the nation's financial system. Of equal significance, the radio address established his presidential image as a friend or neighbour who joined ordinary people in their homes to talk about the problems of the times. [see image below of FDR's first Fireside Chat] In the days that followed, the White House received a huge volume of mail in response to the talk, setting a pattern for subsequent Fireside Chats and establishing a unique dialogue between president and people. Thanks to FDR's 'conspicuous courage, cheerfulness, energy, and resource,' Sir Ronald Lindsay, the British Ambassador reported, '.... the starved loyalties and repressed hero-worship of the country have found in him an outlet and a symbol.'13

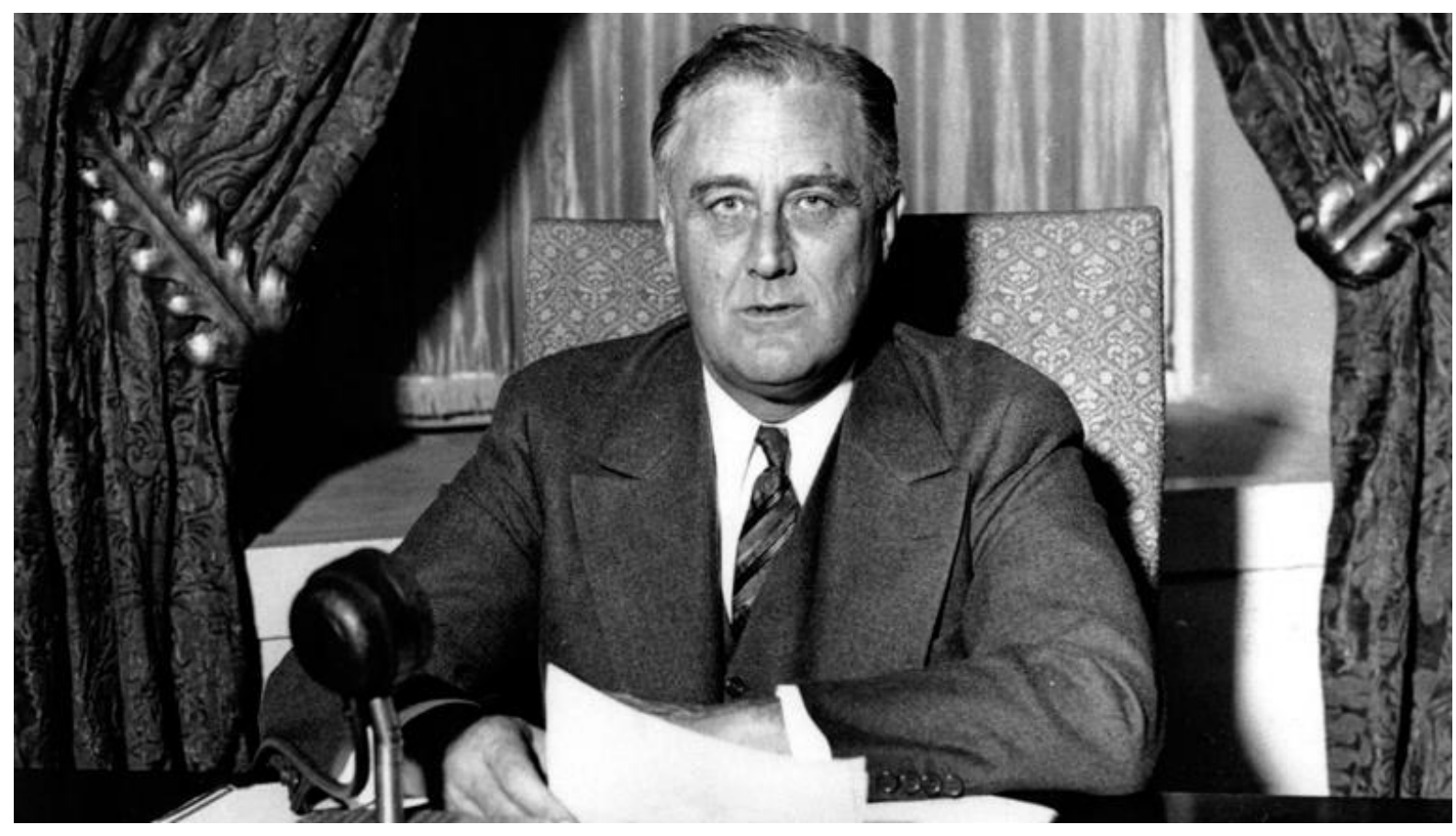


However, some of the measures adopted by Congress during the early months of the New Deal met with more criticism, especially the National Industrial Recovery Act, the Agricultural Adjustment Act and the devaluation of the dollar. FDR delivered two more Fireside Chats - on 7 May and 24 July - to explain and defend his policies directly to the American people, referring in the latter to "the hundred days which had been devoted to the starting of the wheels of the New Deal.' The 'Bombshell message' that Roosevelt sent to the World Economic Conference in London on 3 July rounded off this intense period of activism. Rebuking the delegates for their continued adherence to the 'old fetishes of so-called international bankers,' FDR told them not to focus on currency stabilisation but to discuss trade policy and other economic issues. Now increasingly concerned at the direction of the New Deal, Sir Ronald Lindsay commented of the president whom he had so greatly praised just a short time ago: 'Mr Roosevelt is, in these complex matters, an almost complete amateur and an opportunist, in a country where both types tend to predominate. ${ }^{14}$

While Roosevelt's image abroad was now dented, at home public opinion and the press remained largely favourable to him. The 'Bombshell message' was regarded in the US as a financial declaration of independence from Europe. Frank Knox, a leading Republican and the owner of the influential Chicago Daily News, who had served under TR in the 'Rough Riders' during the Spanish American War, welcomed what he called its dose of 'Rooseveltian realism, which does not hesitate to call a spade a spade'. Henry Stimson, another Republican admirer of Theodore Roosevelt, arriving in Britain on 12 July on vacation, also approved of Roosevelt's message although not the language that had been employed. He felt that FDR's character was impulsive and similar in this respect to that of Theodore Roosevelt - in whose administration he had served prior to joining the Taft Administration as Secretary of War. ${ }^{15}$ 
The 'Hundred Days' and the 'Bombshell message' consolidated FDR's initial image as a strong leader in the TR mould who was putting the US first. In fact, he had gone beyond TR in his advocacy on behalf of 'the forgotten man,' a stance that Al Smith condemned as a call to 'class warfare.' Smith subsequently joined the Liberty League, an organization of conservative businessmen and politicians formed to defend 'American values' against the perceived radicalism of the New Deal. In response to their accusations that he was acting like a dictator, Roosevelt insisted that he was defending American democracy by safeguarding ordinary people from the economic ravages of the Great Depression. The increased congressional majorities won by the Democrats in the 1934 midterm elections suggested that FDR was winning the argument against his conservative critics, but he now faced grassroots anger that the New Deal had not gone far enough to help the common people. Senator Huey Long of Louisiana, Father Charles Coughlin, the so-called 'radio priest,' and Francis Townsend, the California physician who advocated old-age pensions, became the champions of this populist protest. Long posed the greatest danger to FDR's re-election because he could draw many votes away from the president by running as a third-party candidate, but his assassination in September 1935 eliminated that threat. Even so, Roosevelt was aware that Coughlin and Townsend could still mobilize popular opposition if the New Deal failed to deliver reforms that benefited the mass of people. ${ }^{16}$

FDR's relationship with the media was obviously an important ingredient in his electoral success. He felt that most newspaper owners, exemplified by Chicago Tribune publisher Robert 'Colonel' McCormick, were largely pro-business GOP supporters. By contrast, with the help of a very efficient press office headed by Steve Early, Roosevelt developed a good relationship with most journalists. Reporters valued FDR's bi-weekly press conferences as a constant source of news, appreciated not having to submit written questions in advance as required by his Republican predecessors, and enjoyed interacting 
with a president so willing to give them copy. By and large newspaper correspondents wrote favourable articles about FDR throughout his first term, but editorial opinion grew more critical as the New Deal became more interventionist on socio-economic issues in 1935 . The Revenue Act established a 'wealth tax,' the Social Security Act introduced federal old age pensions and unemployment insurance, and the National Labor Relations Act greatly strengthened trade union rights. Breaking with Roosevelt, whom he had initially supported, media mogul William Randolph Hearst made his newspaper chain a powerful voice of opposition to the New Deal. ${ }^{17}$

Faced with the hostility of newspaper owners, FDR valued the radio and newsreels as ways of communicating his message to the public. With some 60 percent of households owning a radio in 1932, the market continued to grow in defiance of economic conditions there were estimated sales of 8 million new sets in 1936 and 9 million in 1937. In 1934 the licensing of radio stations became the responsibility of the newly-established Federal Communications Commission. This independent regulatory agency consisted of five commissioners, nominated by the President and confirmed by Senate to serve for five years, and a chair designated by the President. Although no more than three commissioners could be chosen from the same political party, authority to appoint them became an important presidential power, one that FDR was not shy of using. Through Steve Early, the Roosevelt White House paid close attention to radio station audience sizes and their reporting of the president when broadcasters sought licence renewal. ${ }^{18}$

Newsreels became a significant medium of political communication that featured in virtually every movie-house programme as the silent-film era gave way to the 'talkies.' Their popularity led to the opening of all-newsreel theatres, beginning with the Embassy Theater in New York in November 1929. Seeing a market for pictorial depiction of current affairs, a handful of newsreel chains opened houses in other cities as the 1930s progressed. According 
to W. French Githens, managing editor of Pathé News and founder of Newsreel Theaters Inc, 'We soon discovered that in Franklin Delano Roosevelt we had the greatest single attraction. Announcement of his fireside chats, which were always filmed, brought hundreds of patrons to the theater. Anti-New Dealers came to hiss. The vigorous years of the New Deal under FDR and the rise of Mussolini, Hitler, Stalin, and Chiang Kai-shek aroused great interest in newsreels.' 19

The 'vigorous years of the New Deal' saw an unprecedented amount of legislation that empowered federal involvement in new areas of economic regulation, social welfare provision, and protection of labour rights. In Roosevelt's first term, the principal opposition to these innovations came not from the Republican party or conservative Democrats but from the Supreme Court. Four of the nine justices on the Court - Pierce Butler, James Clark McReynolds, George Sutherland, and Willis Van Devanter - became known to the press as the 'four horsemen' for their steadfast opposition to key features of the early New Deal as an unconstitutional expansion of federal authority. When joined by Associate Justice Owen Roberts and, on occasions, Chief Justice Charles Evans Hughes in the 1935 term, this conservative bloc invalidated some key Roosveltian measures, notably the National Industrial Relations Act, the Agricultural Adjustment Act, the Railroad Act and the Coal Mining Act. FDR feared that subsequent New Deal reforms such as the Social Security Act and the National Labour Relations Act would be invalidated sooner or later by the conservatives on the Court unless they could be curbed during his second term. ${ }^{20}$

In the meantime, the 1936 presidential election turned into a referendum on Roosevelt's leadership and his reforms. The Republican platform began with the words: 'America is in peril.' Charging that 'the New Deal Administration has dishonoured American traditions,' it urged 'all Americans, irrespective of party, to join us in defense of American institutions.' FDR responded with a stirring speech accepting his party's presidential 
nomination at its national convention in Philadelphia. In the city where the Continental Congress had adopted the Declaration of Independence in 1776, the president reminded his audience that the Founding Fathers had ended political tyranny, but he went on to warn that the rise of modern industry had brought with it a new tyranny of 'economic royalists,' whose 'new dynasties' threatened democracy by creating huge inequalities of wealth. 'Here in America,' he declared, 'we are waging a great and successful war. It is not alone a war against want and destitution and economic demoralization. It is more than that; it is a war for the survival of democracy. We are fighting to save a great and precious form of government for ourselves and for the world'. ${ }^{21}$

\section{The Supreme Court battle of 1937}

FDR believed that there was only one issue in the 1936 presidential election - himself. To the extent that it was a contest between two contrasting images of Roosevelt, the outcome was a clear victory for FDR as reformer and 'Great Campaigner' over FDR as threat to constitutional democracy. He won a huge personal victory, gaining 46 out of 48 states (all except Maine and Vermont), 523 electoral votes against 8 for his Republican opponent, Governor Alf Landon of Kansas, and almost 61 percent of the popular vote. Thanks to his coattails, the Democrats increased their already large majorities in both houses of Congress. To some pundits, the result put the continued existence of the Republican party in doubt. The Union party that Father Coughlin and Francis Townsend had organized to promote William Lemke's independent presidential candidacy had proved a damp squib. After its rout, the 'radio priest,' whose anti-Roosevelt tirades had reached a wide audience, announced that he was going off the air. ${ }^{22}$

FDR barely mentioned the Supreme Court during the campaign, but his smashing electoral victory emboldened him to propose a radical plan for its reorganization. In his inaugural address on 20 January 1937, he acknowledged that the state of the nation was much 
improved in comparison to its condition four years earlier, but much remained to be done to fulfil 'our progressive purpose.' Encapsulating the New Deal's unfinished business in a short, simple, but striking sentence, Roosevelt declared, 'I see one-third of a nation illhoused, ill-clad, ill-nourished.' Anxious that the Supreme Court might invalidate his initiatives to help those in most need, he was in a great hurry to reform it without going through the drawn-out process of constitutional amendment. Based on the advice of Attorney-General Homer Cummings, the president intended to enlarge the Court by appointing up to six new justices. The patently devious rationale for such a dramatic change entailed dressing it up as part of a broader Judiciary Bill based on the need for 'new blood' in view of the advanced age of some current justices. FDR kept the plan a closely guarded secret that he did not share with Democratic National Committee chair James Farley and party leaders in Congress until the eve of making it public at his press conference on 5 February $1937 .^{23}$

Republicans predictably opposed what soon became known as FDR's 'court-packing' plan, seeing it as vindication of their 1936 campaign warnings about the New Deal's threat to American institutions. Frank Knox, the GOP's vice-presidential candidate who had compared FDR to TR in 1933, now saw nothing in common between them apart from their family name. Henry Stimson, whom TR had appointed a US attorney, was also critical of his cousin's disrespect for the Constitution in the pages of his diary. Republican traditionalists like Herbert Hoover were also up in arms at the threat to the separation of the powers. ${ }^{24}$ For the most part, however, Republicans left it to the Democrats to criticise the plan, which many of them proceeded to do - in the press and on the radio.

Opposition in the Senate from conservative Democrats like Harry Byrd of Virginia and Josiah Bailey of North Carolina was to be expected, but some prominent liberals joined in the attack. Burton Wheeler of Montana, hitherto a strong New Dealer, played a leading 
role in masterminding the defeat of the Judiciary Bill. In addition to putting forward an alternative proposal for popular review of Supreme Court decisions, first suggested by Theodore Roosevelt in 1912, he obtained a private letter from Chief Justice Hughes containing reassurances that the nine justices were up to date with their docket and did not require additional appointments to keep on top of their work. ${ }^{25}$

In also coming out against the court-packing plan, several eminent journalists portrayed FDR as posing a threat to America's constitutional democracy. Most damningly, Walter Lippmann noted the similarities between his proposed judicial reform and the actions of dictators in Europe. In his view, FDR was to all intents and purposes acting on the assumption that democracy could not function in America unless power was centralized in his hands, but that development would only destroy what it was intended to save. ${ }^{26}$ Even normally supportive newspapers like the New York Times accused Roosevelt of engaging in 'political sharp practice' by hiding a major constitutional change 'under the name of judicial reform.' This was a mild rebuke in comparison with editorials elsewhere that depicted Roosevelt as a tyrant in the making. 'Nothing can disguise the naked sword that has been drawn,' opined the Brooklyn Eagle. 'Already possessing far more power than any peace-time President has ever held, with an unprecedented control over both Houses of Congress, he has asked for power over the judiciary. This is too much power for any man to hold in a country that still calls itself a democracy.' Disdaining FDR's failure to mention his plans during the recent election campaign, the Baltimore Sun accused him of being 'disingenuous with the people. ${ }^{27}$

\section{Losing the battle}

This widespread attack on the Court plan put FDR on the defensive. He initially hoped that speeches and interviews from loyalists like Secretary of the Interior Harold Ickes and pressure on Democratic members of Congress from New Deal groups with an interest in 
Court reform, notably labour unions, would suffice. Before long, however, it was clear that he would have to make an open appeal for support. With the fox giving way to the lion, FDR launched a double-pronged attack in early March - addressed first to his party and then to the public in a Fireside Chat. At a Victory Dinner at the Mayflower Hotel, Washington DC, on 4 March, he called on Democrats to be bold. Mindful of the rise of dictators in Europe and of home-grown demagogues in the mould of Huey Long, he warned: 'If we do not have the courage to lead the American people where they want to go, someone else will.' Harold Ickes adjudged this address 'the greatest he has ever made ... it will go down in history as one of the outstanding speeches delivered by an American statesman. ${ }^{28}$

A few days later FDR confided to Ickes that he was struggling with how to frame his Fireside Chat. In the event, he emulated his second Inaugural Address in contending that America now faced a crisis greater than the one in March 1933 - 'the need to meet the unanswered challenge of one-third of a Nation ill-nourished, ill-clad, ill-housed.' Over the past half-century, he warned, the balance of power between the three branches of national government had been undermined by the judiciary 'in direct contradiction of the high purposes of the framers of the Constitution.' Ending on a high note, he refuted charges of acting like a dictator: 'It is my purpose to restore that balance. You who know me will accept my solemn assurance that in a world in which democracy is under attack, I seek to make American democracy succeed. ${ }^{29}$

Voicing the scepticism of the New York Times, Washington bureau chief Arthur Krock anticipated that FDR would appoint 'party men' rather than accomplished jurists to the Supreme Court. Public reaction to the fireside address was more favourable but did not elicit the same level of support as FDR's earliest efforts. The White House received many letters from Democratic voters and self-declared independents expressing admiration for the president but declaring him wrong on this issue. Others were very critical of the Court 
proposal as undemocratic and dangerous, with some expressing concern that FDR was aiming to become a dictator. Most correspondents put their trust in FDR to do the right thing because of the 'fearless courage' he had shown in taking on the bankers and corporations. 'We workers are with you to the end of this bitter fight,' wrote one listener, while an AfricanAmerican living in Louisiana called Roosevelt 'a shepherd for your flock' and suggested he nominate a black justice among the new appointments to the Supreme Court. ${ }^{30}$

The Gallup poll findings indicated that FDR's campaign met with some success. Following his Victory Dinner speech and Fireside Chat, respondent approval for the Court plan increased from 41 percent to 46 percent and opposition fell from 50 percent to 44 percent, with 'don't knows' at 9 to 10 percent. Popular support for the plan remained marginally stronger than opposition to it until the Court upheld the National Labor Relations Act of 1935 in a landmark ruling on 4 April. With the urgency of Court reform appearing to decrease, opposition thereafter rose to 46 percent while support fell to 44 percent. Associate Justice Willis Van Devanter's announcement on 18 May that he would retire at the end of the current judicial term then opened the way for FDR to replace one of the 'Four Horsemen' with a liberal nominee. Public support for reform consequently dropped to its lowest point at 31 percent while opposition rose to 45 percent and climbed thereafter to 50 percent. ${ }^{31}$ Gallup polls suggested that public opposition never ran higher than 50 percent and popular approval ranged from 31 percent to 46 percent. Though FDR's support was far from anaemic, it was not sufficiently robust to persuade doubtful members of Congress to vote for the scheme. The sudden death on 14 July of Senate Majority Leader Joseph Robinson of Arkansas, who was leading the fight for judicial reform in the upper chamber and had been promised the first vacancy on the Supreme Court, proved the final blow for presidential hopes. On 22 July the Senate voted by 70 to 20 to send the Judiciary Bill back to committee without the Supreme Court clauses and the resulting Judiciary Act was signed by FDR on 24 August. Explaining 
this outcome, William Leuchtenburg suggested that the 'greater the insecurity of the times, the more people cling to the few institutions that seem unchangeable.' In any event, the Supreme Court plan was dead, and no American president has thereafter attempted to reorganise the judiciary. ${ }^{32}$

\section{Winning the war}

FDR would later claim that he had 'lost the battle but won the war' over judicial change. According to historian James MacGregor Burns, however, the impact of the controversy on Congress and the Democratic party meant that the president had 'lost the battle, won the campaign, but lost the war.' Certainly, FDR had failed to achieve a radical reorganisation of the Supreme Court and the issue had widened the divide between liberal and conservative Democrats, but the event that helped to deliver the coup de grace to the court-packing planthe resignation of Associate Justice Willis Van Devanter - also brought judicial conservatism closer to its Appomattox. This was the first of five judicial vacancies created by retirement or death within a three-year period. By the end of FDR's second term, the Supreme Court had to all intents and purposes become the Roosevelt Court. Four further nominations in his third term confirmed this reality. Only George Washington in the early years of the Supreme Court had nominated more justices. A decade later five of his nominees joined with three of Harry S. Truman's appointees to render the epochal school-desegregation decision, Brown vs. Topeka, under the leadership of liberal Republican Earl Warren, Dwight D. Eisenhower's first judicial nominee. ${ }^{33}$

Following the Judiciary bill defeat, FDR went by train on a tour of the Pacific Northwest to inspect various New Deal public-works projects. In a rear platform address at Boisie, Idaho, the president likened himself to 'an old mythological character by the name of Antaeus,' whose strength redoubled every time his foot touched the ground. 'I feel that I regain strength by just meeting the American people. ${ }^{34}$ The subtext was clear: he may have 
stumbled with Congress, but the people were still with him. A reinvigorated Roosevelt used another Fireside Chat on 12 October to draw a line under the Supreme Court imbroglio. This radio address gave perfect form to Roosevelt's image as a great campaigner through its confident expression in the wellbeing of American democracy.

'Five years of fierce discussion and debate,' the president asserted, 'five years of information through the radio and the moving picture, have taken the whole nation to school in the nation's business. Even those who have most attacked our objectives have, by their very criticism, encouraged the mass of our citizens to think about and understand the issues involved, and understanding, to approve.' FDR had pointedly not referred to the role of the press in his paean to the country's democratic spirit, but he was confident that hostile newspaper owners could not destroy the bond between people and president based on their agreement that activist government was necessary to resolve the nation's problems. Americans, he avowed, 'are less concerned that every detail be immediately right than they are that the direction be right. They know that just so long as we are traveling on the right road, it does not make much difference if occasionally we hit a "Thank you ma'am".,35

Lauding this optimistic address, New York Times radio editor Orrin Dunlap conjured up an arresting image of FDR's peerless skills of political communication through the medium by referring to him as 'a Blondin of the wavelengths,' whose 'all-American voice ... [had] lifted the art of broadcast speaking to lofty heights'. For the political parties planning their 1940 campaign, he continued, 'part of the problem may be to find a voice as well as a man' because politicians and broadcasters were now of one mind that 'no matter how strong a candidate's prestige and character, if he has a weak voice personality on the radio, he has one if not two strikes on him when he steps up to the "mike."' The 'magnetic technique' that made FDR the master of the medium was not a complicated one: 'Naturalness is the keynote. He talks smoothly and in a conversational tone, seldom faltering on a single word; rarely does 
he cough or clear his throat during a half-hour "chat." In Dunlap's estimate, FDR was 'born with a radio personality,' making it 'a difficult assignment' for any other candidate to measure up to him. The question was already being asked: 'Who have the Democrats to offer with a voice like Roosevelt's; who have the Republicans? ${ }^{36}$

Two weeks later, Arthur Krock reflected in the New York Times on FDR's position following the Supreme Court controversy. In his assessment, whatever their divisions over court-packing, conservative Democrats, especially in the South, still had a tribal loyalty to the party, and liberals remained strongly supportive of the president's New Deal. Meanwhile, the GOP's 'strategy of silence' during the Court controversy may have appeared to be clever politics at the time, but it had won them few new adherents. A realignment of political forces would therefore be very difficult to achieve without 'a great leader with a powerful personality and record appealing to the country' and at present FDR was 'the only national leader on the scene or in sight., ${ }^{37}$

FDR's image as a strong leader would arguably suffer more damage from the outcome of the 1938 midterm elections than it had from the Supreme Court controversy. His largely unsuccessful efforts to purge anti-New Deal Democrats by supporting liberal challengers in the primaries raised doubts about his control over his own party. The so-called Roosevelt recession of 1937-38 also did much to precipitate the Republican comeback in the midterms. In the new Congress that met in 1939, the Democrats held majorities in both chambers, but an informal coalition of Republicans and conservative Democrats had the votes to block further significant expansion of the New Deal. Sensing that FDR was at the nadir of his prestige, columnist Raymond Clapper commented '[C]learly ... President Roosevelt could not run for a third term even if he so desired.' ${ }^{38}$ A half-century before Bill Clinton would forge his 'Comeback Kid' image, FDR would mount an even greater political recovery to win four more years as president. 
The international situation and the threat of war in Europe had significant impact on the environment of American politics. As Roosevelt biographer Roger Daniels observed, his annual message in January 1939 and the congressional response to it prefigured his relations with the legislature for the remainder of his presidency: 'As long as his chief concern was national defense and eventually the prosecution of the war, he could usually count on majority support drawn from both sides of the aisle for most of his proposals. But when he endeavoured to expand the New Deal, he would often encounter serious difficulties.' In this address, his avowal to build up America's military strength to keep it safe from attack was broadly well received, but his insistence that the nation's programme of social and economic reform was 'a part of defense as basic as armaments themselves' drew far less support. ${ }^{39}$

The outbreak of war in Europe led to another Fireside Chat on 3 September confirming American neutrality but - unlike Woodrow Wilson in August 1914 - not asking for neutrality in thought as well as action. However, the president did make 'the simple plea that partisanship and selfishness be adjourned; and that national unity be the thought that underlies all others. ${ }^{40}$ Clearly Roosevelt was shifting his image from the rather divisive reformer of the 1930s to the unifying leader of the wartime era. Indeed, from this point in time, all his Fireside Chats would have a war-related theme. In combination with his formal presidential speeches, best exemplified by his 1941 State of the Union address ${ }^{41}$, they would do much to educate Americans about their nation's democratic purpose in eventually joining the conflict. With the dramatic success of the German blitzkrieg in the summer of 1940, FDR effectively created an administration of national unity by appointing eminent Republicans Frank Knox as Navy Secretary and Henry Stimson as Secretary of War. Both had been trenchant critics of his court-packing plan but were strong supporters of his efforts to move American public opinion away from isolationism. 
The apparent imminence of Adolf Hitler's total victory in the European conflict also formed the backdrop to FDR's nomination for an unprecedented third-term as president by the Democratic National Convention in Chicago. His image as a strong and experienced leader was to prove essential in his defeat of his relatively untested Republican challenger, Wendell Willkie, in the November presidential election. This was no landslide victory on the scale of 1940, but it was still a comfortable one by 54.7 to 44.8 percent of the popular vote and by 449 to 82 votes in the Electoral College. In one way, the outcome confirmed the continued importance of the New Deal voter coalition that had formed in support of the Democrats in FDR's first term. In another way, it was also a triumph for the Rooseveltian image. As Republican House minority leader Joseph Martin of Massachusetts later observed, 'There are times, and 1940 was one when the party that seems best able to prosecute a war is invincible. In the last analysis, the people trusted Roosevelt's experience in coping with the situation that confronted the country.' For that reason, it is reasonable to conclude that no other Democratic candidate could have won the presidency in $1940 .{ }^{42}$ FDR was genuinely reluctant to run again but he was determined to uphold both national security and the New Deal. During his third term 'Dr New Deal' became subordinate to 'Dr Win-the-War.' However, the spirit of New Deal reformism never entirely disappeared and would find expression in his 1944 State of the Union address with its vision of promoting an Economic Bill of Rights once the war was won. ${ }^{43}$

\section{Conclusion}

If FDR's image and, indeed, his presidency, were on trial during the Supreme Court episode, the outcome of the 1940 presidential election suggests that he was acquitted by the jury that matters most in American politics - public opinion. The defeat of his judiciary bill did not mean that his powers of persuasion were in decline. The Gallup poll findings suggest that he was able to carry a significant proportion of the population with him, and in the month 
following his Fireside Chat on the Court, a plurality. But in a political system defined by checks and balances there is a limit to the constitutional change that any president can achieve without securing a formal amendment to the Constitution - even one as popular as Roosevelt. However, FDR's radio presence remained a potent weapon in exercising the 'power to persuade' as was demonstrated by his leadership during World War 2, when he delivered over half of his total of thirty Fireside Chats to far larger audiences than in peacetime. In December 1940 his 'garden hose' analogy for Lend Lease and the 'arsenal of democracy' metaphor in his fireside chat showed that FDR retained his rhetorical powers and his mastery as 'the Voice on the Radio' - a mastery that won the admiration of Winston Churchill in beleaguered Britain as well as the President's supporters at home. The 'Great Campaigner' had not lost his touch. ${ }^{44}$

How then do we explain the resilience of the Roosevelt image? Essentially the image of FDR as a charismatic and reforming president had already been established by the start of his second term. As the Gridiron skits suggested, the main issue raised during the Supreme Court controversy centred upon his judgement in adopting the 'Court packing' plan. While some doubted his motives, what concerned many critics were his methods, which would be dangerous in the hands of a dictatorial successor. Had he stood down in 1940 FDR would probably have been regarded by history as a 'near great' President - somewhat akin to Theodore Roosevelt, Woodrow Wilson, and Harry S. Truman. From 1940, however, as the threat from Nazism grew and was reinforced by Japan after the attack on Pearl Harbor, Roosevelt the progressive reformer became Roosevelt the defender of democracy. As James McGregor Burns put it, 'the Lion and the Fox' gave way to the 'Soldier of Freedom' and FDR's image - at home and abroad - as one of America's greatest presidents was assured. ${ }^{45}$ 


\section{Notes [all websites verified 19 November 2018] \\ 1 'Remarks of the President at the Gridiron_Club Dinner, Washington DC,' 10 April 1937,}

http://www.fdrlibrary.marist.edu/_resources/images/msf/msf01473. For FDR's views on the Gridiron dinners, see Winfield, Betty Houchin, FDR and the News Media (New York: Columbia University Press, 1994), p. 60.

2 ‘15 Rubber Stamps in Gridiron “Court,” New York Times [NYT], 11 April 1937.

${ }^{3}$ Leuchtenburg, William E. In the Shadow of FDR: From Harry Truman to Ronald Reagan (Ithaca NY: Cornell University Press, 1983), p. x; Neustadt, Richard, Presidential Power and the Modern Presidents (New York: Macmillan, 1990), pp. 11, 135-137.

${ }^{4}$ Leuchtenburg, Shadow of FDR, pp. vii-xi.

${ }^{5}$ For the classic study of Depression-era politics, see Leuchtenburg, William, E., Franklin D. Roosevelt and the New Deal, 1932-1940 (New York: Harper \& Row, 1963). Excellent political biographies of FDR include: Maney, Patrick, The Roosevelt Presence: The Life and Legacy of FDR (Oakland: University of California, 1998); Hamby, Alonzo, Man of Destiny: FDR and the Making of the American Century (New York: Basic Books, 2015); and Daniels, Roger, Franklin D. Roosevelt: Road to the New Deal, 1882-1939 and Franklin D. Roosevelt: The War Years, 1939-1945 (Urbana: University of Illinois Press, 2015 and 2016).

6 Burns, James MacGregor, Roosevelt: The Lion and the Fox ( New York: Harcourt, Brace, 1956), p. ix; Dallek, Robert, Franklin D Roosevelt: A Political Life (London: Allen Lane, 2017), p. x; Morgan, Iwan, 'The top US presidents: first poll of UK experts,' https://www.bbc.co.uk/news/world-us-canada-12195111. Regarding Roosevelt's top spot in the latter, see: McCulloch, Tony, 'Simply the Best: FDR as America's Number One President,' in Michael Patrick Cullinane and Clare Frances Elliott, eds., Perspectives on Presidential Leadership: An International View of the White House (New York: Routledge, 2014), pp. 113-31.

${ }^{7}$ Burns, Lion and Fox, pp. 47-66; Maney, Roosevelt Presence, pp. 12-29; Dallek, Roosevelt, pp. 40-69.

${ }^{8}$ Burns, Lion and Fox, pp. 67-80; Dallek, Roosevelt, pp.70-73; 'Unanimous for Roosevelt,' NYT, 7 July 1920; FDR newsreel,1920-1932, https://www.youtube.com/watch?v=Fl6WBhavFgU

${ }^{9}$ Burns, Lion and Fox, pp.83-122; Dallek, Roosevelt, pp. 74-100; 'Roosevelt Offers Name of Governor Smith,' NYT, 27 June 1924; 'Roosevelt Names New York Governor,' NYT, 28 June 1928.

10 'Address Accepting the Democratic Presidential Nomination in Chicago,' 2 July 1932, Gerhard Peters and John T Woolley, The American Presidency Project [hereafter APP], https://www.presidency.ucsb.edu/node/275484; Ritchie, Donald A., Electing FDR: The New Deal Campaign of 1932 (Lawrence: University Press of Kansas, 2007).

${ }^{11}$ Gallagher, Hugh Gregory, FDR's Splendid Deception: The Moving Story of FDR's Massive Disability - And the Intense Efforts to Keep It from the Public (St. Petersburg FL: 
Vandamere, 1999); Tobin, James, The Man He Became: How FDR Defied Polio to Win the Presidency (New York: Simon \& Schuster, 2013).

${ }^{12}$ Alter, Jonathan, The Defining Moment: FDR's Hundred Days and the Triumph of Hope (New York: Simon \& Schuster, 2006), pp. 245-52; 'Fireside Chat on Banking,' 12 March 1933, APP, https://www.presidency.ucsb.edu/node/207762; Greenberg, David, Republic of Spin: An Inside History of the American Presidency (New York: Norton, 2016), pp. 189-98.

${ }^{13}$ Levine, Lawrence, and Cornelia Levine, The People and the President: America's Conversation with FDR (Boston: Beacon Press, 2002), pp. 29-59; Leuchtenburg, William E., The FDR Years: On Roosevelt and His Legacy (New York: Columbia University Press, 1995), p. 7.

${ }^{14}$ Burns, Lion and Fox, pp. 176-179; Dallek, Roosevelt, pp. 133-166 ; FDR, 'Wireless to the London Conference,' 3 July 1933, APP, https://www.presidency.ucsb.edu/node/208290; Lindsay, 27 July 1933, Foreign Office 371, 16600, A5782/17/45, UK National Archives, Kew.

${ }^{15}$ Knox, Frank, 'Boldness of President Clears Away Fog', Chicago Daily News, 3 July 1933; Henry Stimson Diary, Volume 26, 14 and 16 July 1933, Stirling Library, Yale University, New Haven.

${ }^{16}$ Burns, Lion and Fox, pp. 161- 226; Brinkley, Alan, Voices of Protest: Huey Long, Father Coughlin, and the Great Depression (New York: Knopf, 1982), pp. 169-93.

${ }^{17}$ White, Graham, FDR and the Press (Chicago, Chicago University Press, 1979), pp. 5-24, 49-52; Winfield, FDR and the News Media, pp. 27-51, 127-132.

${ }^{18}$ Winfield, FDR and News Media. Pp. 103-125; Ryan, Halford R., Franklin D Roosevelt's Rhetorical Presidency (Westport CT: Praeger, 1988), pp. 109-130; Craig, Douglas B., Fireside Politics: Radio and Political Culture in the United States, 1920-1940 (Baltimore: Johns Hopkins University Press, 2000).

19 Fielding, Raymond, The American Newsreel: A Complete History, 1911-1967, $2^{\text {nd }}$ ed. (Jefferson NC: McFarland, 2006), p. 124.

${ }^{20}$ Burns, Lion and Fox, pp. 227-246; Daniels, FDR: Road to New Deal, pp. 230-233, 253255.

21 'Republican Party Platform of 1936,' 9 June 1936, APP, https://www.presidency.ucsb.edu/node/273386; FDR, 'Acceptance Speech for the

Renomination for the Presidency, Philadelphia, Pa.,' 27 June 1936, APP, https://www.presidency.ucsb.edu/node/208917 (accessed 11 Nov 2018).

${ }^{22}$ Leuchtenburg, William E., 'The Election of 1936,' in Leuchtenburg, The FDR Years, 10158.

${ }^{23}$ For the Supreme Court battle see Leuchtenburg, William E., The Supreme Court Reborn: The Constitutional Revolution in the Age of Roosevelt (New York: Oxford University Press, 1995); and Shesol, Jeff, Supreme Power: Franklin Roosevelt vs the Supreme Court (New 
York: Norton, 2010). For historiographical analysis, see: Shaw, Stephen 'The Supreme Court,' in William Pederson, ed., A Companion to Franklin D. Roosevelt (Hoboken NJ: Blackwell Publishing, 2011), 427-441.

${ }^{24}$ Krock, Arthur, 'In the Nation - Two Results of Supreme Court Argument,' NYT, 10 February 1937. For Republican responses, see: Knox, editorial, Chicago Daily News, 6 February 1937; and Stimson Diary, Volume 28, 27 March 1937.

25 McKenna, Marian C., 'Prelude to Tyranny: Wheeler, FDR, and the 1937 Court Fight', Pacific Historical Review, 62 (November 1993): 405-431; Wheeler, Burton K., Yankee From the West (New York, Doubleday, 1962), pp. 320-323.

${ }^{26}$ Krome, Frederick, 'From Liberal Philosophy to Conservative Ideology? Walter Lippmann's Opposition to the New Deal,' Journal of American Culture, 10 (Spring 1987) : 57-64; Ronald Steel, Walter Lippmann and the American Century (Livingston NJ: Transaction Publishers, 1999), pp. 319-326.

${ }^{27}$ White, FDR and the Press, pp. 69-79; 'Opinions of the Nation's Press on Court Plan,' NYT, 6 February 1937.

28 'Address to Democratic Victory Dinner, Washington, DC,' 4 March 1937, APP, https://www.presidency.ucsb.edu/node/209418; Ickes, Harold, The Secret Diary of Harold Ickes, Vol. II: The Inside Struggle, 1936-1939 (New York: Simon and Schuster, 1954) [27 February 1937], p. 88.

29 'Fireside Chat,' 9 March 1937, APP, https://www.presidency.ucsb.edu/node/209434; Ryan, Rhetorical Presidency, 121-124 ; Ickes, Secret Diary, II, 15 March 1937, 95.

${ }^{30}$ Editorial, NYT, 11 March 1937; Krock, 'In Washington - a Formula for Choosing Supreme Court Judges,' NYT, 11 March 1937; Levine and Levine, The People and the President, 163200.

${ }^{31}$ Caldeira, Gregory A., 'Public Opinion and the US Supreme Court: FDR's Court-Packing Plan,' American Political Science Review, 81 (December 1987): 1139-1153.

${ }^{32}$ Leuchtenburg, FDR and New Deal, pp. 232-36; McKenna, 'Prelude to Tyranny,' pp. 430431; Caldeira, 'Public Opinion,' pp. 1139-1140.

${ }^{33}$ Burns, Lion and Fox, p. 315; Urofsky, Melvyn, 'The Roosevelt Court,' in William Chafe, ed., The Achievements of American Liberalism: The New Deal and Its Legacies (New York: Columbia University Press, 2003), pp. 63-98.

34 'Remarks at Boise, Idaho,' 27 September 1937, APP, https://www.presidency.ucsb.edu/node/208784

35 ‘Fireside Chat,' 12 October 1937, APP, https://www.presidency.ucsb.edu/node/208891.

${ }^{36}$ Dunlap, Orrin, 'Speaking of Voices,' NYT, 7 November 1937. See too: Ryfe, David Michael, 'Franklin Roosevelt and the Fireside Chats,' Journal of Communication, 49 (December 1999): 80-103. 
${ }^{37}$ Krock, 'Roosevelt Shapes the Line Up for 1940,' NYT, 24 October 1937.

${ }^{38}$ Clapper, Raymond, 'Return of the Two-Party System,' Current History, 49 (December 1938), 14. For the politics of 1938, see Dunn, Susan, Roosevelt's Purge: How FDR Fought to Change the Democratic Party (Cambridge MA: Belknap Press, 2010).

${ }^{39}$ Daniels, FDR: War Years, 1; 'Annual Message to Congress,' 4 January 1939, APP, http://www.presidency.ucsb.edu/ws/?pid=15684.

40‘Fireside Chat,' 3 September 1939, APP, https://www.presidency.ucsb.edu/node/209990.

${ }^{41}$ See Engel, Jeffrey A., ed., The Four Freedoms: Franklin D. Roosevelt and the Evolution of An American Idea (New York: Oxford University Press, 2016).

${ }^{42}$ Martin, Joseph, My First Fifty Years in Politics (New York: McGraw-Hill, 1960), 120. For the 1940 election see: Dunn, Susan, 1940: FDR, Willkie, Lindbergh, Hitler - the Election Amid the Storm (New Haven CT: Yale University Press, 2013); and Jeffries, John, A Third Term for FDR: The Election of 1940 (Lawrence: University Press of Kansas, 2017).

43 'State of the Union Address,' 11 January 1944, http://www.fdrlibrary.marist.edu/archives/stateoftheunion.html

44 'Press Conference,' 17 December 1940, APP,

https://www.presidency.ucsb.edu/node/209409; 'Fireside Chat,' 29 December 1940, APP, https://www.presidency.ucsb.edu/node/209416.

${ }^{45}$ Burns, James MacGregor, Roosevelt: The Soldier of Freedom, 1940-1945 (NY: Harcourt Brace and Company, 1970), pp. ix-xiv. 